\title{
Student community engagement for employability and entrepreneurship in Senegal
}

\author{
Lamine Kane, Aliou Guissé and Latyr Diouf
}

\section{History}

After connecting online, Lamine Kane of the sub-Saharan Africa Participatory Action Research Network (REPAS) and Juliet Millican from the University of Brighton used a travel grant from the British Council to meet for exploratory discussions in Dakar with members of REPAS, the Department of Applied Economics (ENEA) at Cheikh Diop University (UCAD), and nearby local communities. These discussions led to the joint preparation of a full project proposal, which was funded by a partnership grant from the British Council.

\section{Context}

Senegal is a former French colony and Dakar was the base from which France conceived and implemented its 'assimilation policy', which aimed to make Senegalese citizens French and to integrate them into the French culture and nation. To this end, education was assigned the role of familiarizing students in the colonies with the European order - economic, social and moral - as a first step towards integration. African students read European textbooks and wrote essays on winter, studied central heating and learned how cherries were harvested! Today, more than forty years after independence, the Senegalese education system remains both alien and aloof from social reality. Recently, Mor Talla Kane, head of the National Employers Executive Board, declared that 90 per cent of curriculum content in higher education has no connection whatsoever to the job market.

Senegal's economy faces many challenges, such as: deterioration of commodity prices in the world markets and its side effects on the local economy; dry, arid land and low rainfall in a country in which agriculture employs 70 per cent of the population and accounts for two-thirds of export revenues; and rapid population growth. The legacy of the failed structural adjustment programmes of the 1980s imposed by the International Monetary Fund and World Bank is evident in contemporary Senegal's high public debt and chronic economic problems, particularly high unemployment. Despite all this, however, the country of Teranga is a stable nation with a well-known tradition of commitment to both democracy and human rights in Africa. 


\section{The project}

It was against this backdrop that the partners launched their new project. The initiative aimed to pilot a new six-month postgraduate course for students from Cheikh Anta Diop University and ENEA leading to a Certificate in Community Engagement for Employability and Entrepreneurship. Part of the course involved a period of practice in a village setting, where students worked on an entrepreneurial project. Their initial training was supported by four one-week, university-based modules on: entrepreneurship and social enterprise (particularly in a village setting) and employment-ready skills; sustainable development and environmental protection, community-based research; and CV/résumé writing and interview skills. The project ran for eighteen months between 2009 and 2011.

From the outset of the programme, the objectives were twofold: (1) to create sustainable partnerships between the communities and the university in a country where this rarely happened, to enable the two entities to learn from and influence each other; and (2) to influence university curriculum in such a way that it would accept alternative pedagogies and opportunities for using experiential, applied and community-based learning and review its policies of teaching, learning and grading systems (e. g., the introduction of credits for student placements in the community). These objectives did not change as the project progressed. However, the principals noted that some academics proved to be change resistant - hesitant in accepting and using alternative pedagogies and changing their grading systems.

\section{Organization/structure}

The main organizational structure for the project was the Steering Committee (SC). The SC was composed of the Project Coordinator (Lamine Kane); Prof. Aliou Guissé and Prof. Babacar Diop, both UCAD Representatives (Prof. Guissé was also a Sectoral Coordinator of Niakhene village activities); Dr Latyr Diouf, ENEA Representative and Sectoral Coordinator of Yeba village activities; Mika Lom, REPAS Representative; and Sectoral Representatives from the Mboro and Pikine communities.

In terms of programming sites, the project worked in four villages. Each site regularly hosted students sent to work with communities on development projects. The division of labour in each community was not predetermined. Instead, the project depended on local group dynamics to define the project and participants' responsibilities. In Mboro, for example, where local citizens were very experienced in credit and savings schemes, students played, at the beginning at least, a very limited role. In other cases, such as that of the Niakehene community, students and citizens worked hand in hand in the village garden project, both teaching and learning from one another. 


\section{Stages}

With regard to the stages of the project, the first stage entailed the design and launch of the course. The course was opened to graduates of Cheikh Diop University who were unable to find work after graduation; twenty students were recruited. The second stage involved training the students in the four university-based modules, enabling the students to get to know each other. The third stage focused on facilitating student internships and experiences in the villages. A fourth stage involved the organizing of a regional conference on studentcommunity engagement and its role in increasing employability. Held in early 2011 and involving academics, practitioners and international partners working in sub-Saharan Africa, this conference also sought to influence both undergraduate and postgraduate approaches to teaching and learning.

\section{Methods}

The core element of the programme's approach was the student internship component. For their internships, students were expected to immerse themselves in a village setting and work closely with the community to assess local needs and design and implement participatory local projects. For example, students at Yeba designed an anti-erosion village project, while those at Pikine and Moboro set up revolving credit schemes with local women's associations, supporting them with adult literacy programmes. At Niakhene, students worked on a women's gardens project that was also supported by adult literacy programmes.

At the beginning of the course, the project made agreements with the communities that the communities would: accommodate the students during their stay in the village; work closely with the students to learn but also to teach on the basis of their own experience and social praxis; and, together with the students, assess their own needs, evaluate the cost of those needs and present findings to the project for funding local initiatives. Agreements were also made by the project with students, who agreed to: spend two sessions of three weeks each in a village setting and work with the community on project activities; accept living in rural settings and conditions; receive a symbolic stipend to cover their upkeep; and care for their own food and upkeep.

\section{Challenges}

In practice, however, some of these agreements were not respected. For instance, a dispute arose in Mboro, where a group of six students developed serious problems with the local community. At that site, the students worked on income-generating activities, and credit and savings, with a well-established local development association. The association was to receive money from the project each month and distribute it as loans to local individuals running micro-businesses, who, in turn, were obligated to repay a portion of their loans at the end of the month. Literacy programmes also supported this effort. 
However, two problems arose at this site. First, during their stay, the students hid their stipends, wanting to be housed and fed by the community for free. In the middle of a recession, community households expected and needed contributions from the students, which were not forthcoming. The students were labelled parasites and cheaters by the villagers, who decided not to cooperate with the students during their second placement stay. The second problem was that the members of the local development association proved to be more experienced than the students in the field of microcredit. The students felt inferior in comparison to these association members. In response to these two problems, SC members visited Mboro and held discussions with all parties. SC members suggested to the students that they use their own money for food, lodging and other needs while at their field site, and that the students work with weaker members of the development association who could use student assistance in their micro-business activities.

The project faced another, more fundamental issue when the students in the course went on strike, demanding an increase in their living stipend. Strikes are common, and disruptive, in the Senegalese education system. Explaining to the students that the project overall had a limited budget, the Steering Committee tried to resolve this dispute, but found that its own committee members were divided on the issue. The students maintained their demands. In the end, the SC agreed to a substantial increase in the stipend. This decision created serious problems for the management of the project.

\section{Outcomes}

Many diverse outcomes were generated by the project. From the community standpoint, villagers gained extensive literacy skills, notably basic numeracy skills among women in Pikine and Niakhene, which raised both their confidence and their commercial effectiveness. The communities also gained knowledge of how to dig furrows and sow seeds more effectively for garden vegetables for both household consumption and sale. From the student standpoint, they learned to use participatory rapid appraisal methods, to plough and plant seeds, and to fight back soil erosion. In Yeba, for example, the students worked with villagers to construct dikes and dug pits to retain the water and filter it out, making Yeba less vulnerable to torrential rains and flooding from the surrounding hills.

\section{Impacts}

With regard to the theory of higher education, community-university partnership is a new concept in Senegal - a country where academics traditionally have had little or no contact with the grass roots. In the early 1980s, an education reform commission of the then-socialist national government proposed linking education more closely to the social environment surrounding it. But these recommendations were not acted upon when the structural adjustment programme, with its severe cuts to health and education, came into force. Nonetheless, while the great 
majority of academic institutions still remain aloof and distant from social reality and praxis, the new university-community experiment reported on here has prompted many academics to learn more about alternative approaches to teaching and learning. In terms of policy, alternative approaches are also gaining ground in Senegal every day. The last two vice chancellors at Cheikh Anta Diop University have been very progressive on these questions. But the institutions - the university and the ministry - are proving to be quite resistant to change.

In the communities, it is known that more than 800 individuals were directly impacted by the project across the four project sites; in the long term, it is expected that the project's impacts will reach some 11,000 residents. Yet some results are already evident on the ground. In Yeba town, for example, the lives of local people are more secure as a result of better erosion control, and, as one villager put it, the town has now come back to life. Moreover, some nearby villages can replicate the Yeba methods to reduce the threats to their people. For their part, the villagers in Niakhene report that the community garden has changed their food habits - they now eat more vegetables, in addition to their traditional cereals, and thus gain more diet-enriching vitamins - and there is greater food security in the village. Local project members were given the opportunity of purchasing the vegetables produced by the garden at lower cost; the rest of the produce is sold daily at local and distant markets. In turn, this revenue will be redistributed back into the community by its general assembly.

\section{Success factors}

Six main factors account for the success of this project. First, there was a democratic spirit among steering committee members; discussions were free and open and decisions were made by consensus. Second, all stakeholders were deeply committed to the well-being of the project, notwithstanding the fact that some, such as the students, also defended their personal interests. Third, the university opened its doors to community representatives whenever there were workshops, seminars or meetings; consequently, rural and illiterate men and women are now comfortable using the university campus and exchange freely and openly with academics. Fourth, university academics interacted with communities in rural settings, living in rural conditions, and eating and sleeping in the same facilities as rural citizens. Fifth, the project used a range of communication challenge to promote attitudinal change among all stakeholders, including radio broadcasts and newspaper articles. Finally, the active involvement of local leaders - notably politicians and religious leaders at public meetings - was mobilized to positively influence the community to participate in the project and to view communityuniversity partnerships in a positive light.

\section{Lessons}

Two overarching lessons can be drawn from this project: 
1 Every human being is knowledgeable. For example, faculty and students learned from villagers how to use plants to cure illness and disease, drawing on centuries-old traditional knowledge.

2 Knowledge implies social change over the decades, small farmers in Senegal have learned about the importance of crop diversification and of getting fair prices for their labour and produce. This project generated for them new knowledge and new changes that improved their livelihoods.

\section{Recommendations}

Five recommendations arise from the experience of the case reviewed here, as follows:

1 Policymakers should promote alternative approaches in teaching and learning, particularly in francophone universities.

2 Universities should promote awareness among academics of the value of experiential and practical work in their teaching and learning activities.

3 Governments and universities should facilitate the creation of local networks involving universities, employers, community groups (both NGOs and community-based organizations) and community members, in order to encourage and assist universities in reviewing their policies of teaching, learning and grading.

4 Funding agencies should support the strengthening of local and international networks and opportunities to share the value of participatory action research and community-university partnerships across sub-Saharan Africa.

5 Funding agencies should promote national and regional awareness of the value of student-community engagement programmes for employability, and its contribution to the global understanding of the potential of partnerships between universities and local communities. 